\title{
PENGARUH KOMPENSASI LANGSUNG DAN KOMPENSASI TIDAK LANGSUNG TERHADAP KINERJA KARYAWAN BAGIAN STAFF OPERASIONAL PT PRANATA JAYA ABADI BANJARAN
}

\author{
Wandy Zulkarnaen \\ Risa Herlina \\ STIE Muhammadiyah Bandung, Jl. Karapitan No.143 Bandung \\ Email : wandy.zulkarnaen@stiemb.ac.id
}

\begin{abstract}
Abstrak
Sumber daya manusia merupakan faktor penunjang agar perusahaan tetap bertahan di dalam persaingan. Kompensasi memegang peranan penting dalam meningkatkan kinerja karyawan, salah satu alasan utama seseorang bekerja adalah untuk memenuhi kebutuhan hidupnya. Seseorang akan bekerja maksimal agar mendapatkan kompensasi yang sesuai dengan harapan. Kebijakan kompensasi selain memberikan imbalan kepada karyawan atas pekerjaan yang dilakukan karyawan juga merupakan salah satu cara untuk mempertahankan karyawan yang potensial.

Berdasarkan variabel-variabel yang diteliti, maka metode penelitian yang digunakan dalam penelitian ini adalah metode deskriptif dan asosiatif. Penelitian deskriptif adalah penelitian yang dilakukan untuk mengetahui nilai variabel mandiri dan tidak membuat perbandingan variabel dengan variabel lain Penelitian deskriptif disini bertujuan untuk memperoleh gambaran mengenai kompensasi langsung, kompensasi tidak langsung dan kinerja karyawan pada PT Pranata Jaya Abadi. Sedangkan Sedangkan metode penelitian asosiatif adalah penelitian yang bertujuan untuk mengetahui pengaruh ataupun juga hubungan antara dua variabel atau lebih.

Hasil penelitian ini menunjukan sebuah persamaan regresi linier berganda sebagai berikut : $\mathrm{Y}=0,414+0,997 \mathrm{X}_{1}+0,866 \mathrm{X}_{2}$, yang dapat diartikan sebagai bahwa variabel $\mathrm{X}_{1}$ dan $\mathrm{X}_{2}$ bernilai nol (0), maka variabel $\mathrm{Y}$ akan bernilai 0,414 satuan; jika kompensasi langsung $\left(\mathrm{X}_{1}\right)$ meningkat sebesar satu satuan dan variabel lainnya konstan, maka variabel $\mathrm{Y}$ akan meningkat sebesar 0,997 satuan, serta jika kompensasi tidak langsung $\left(\mathrm{X}_{2}\right)$ meningkat sebesar satu satuan dan variabel lainnya konstan, maka variabel Y akan meningkat sebesar 0,866 satuan.

Kesimpulan dari penelitian ini diperoleh nilai koefisien determinasi sebesar $82,7 \%$ atau nilai 0,827 yang menunjukkan arti bahwa kompensasi langsung $\left(\mathrm{X}_{1}\right)$ dan kompensasi tidak langsung $\left(\mathrm{X}_{2}\right)$ memberikan pengaruh simultan (bersama-sama) sebesar $82,7 \%$ terhadap kinerja karyawan (Y). Sedangkan sisanya sebesar 17,3\% dipengaruhi oleh faktor lain yang diabaikan penulis. Adapun nilai Adjusted $\mathrm{R}^{2} \quad 0,820$ atau nilai sebesar $82,0 \%$ yang menunjukkan arti bahwa, bila ada variabel bebas lain yang akan dimasukkan, variabel kompensasi langsung dan tidak langsung, tetap berpengaruh sebesar $82,0 \%$. Terhadap kinerja karyawan.
\end{abstract}

Kata kunci : Kompensasi Langsung, Kompensasi Tidak Langsung dan Kinerja 


\begin{abstract}
Human resources are a supporting factor for companies to survive in competition. Compensation plays an important role in improving employee performance, one of the main reasons a person works is to make ends meet. Someone will work maximally to get the compensation in accordance with expectations. The compensation policy in addition to rewarding employees for the work performed by employees is also one way to retain potential employees.

Based on the variables studied, the research method used in this research is descriptive and associative method. Descriptive research is a study conducted to determine the value of independent variables and does not make the comparison of variables with other variables Descriptive research here aims to obtain a picture of direct compensation, indirect compensation and employee performance at PT Pranata Jaya Abadi. While the method of associative research is research that aims to determine the influence or also the relationship between two variables or more.

The results of this study show a multiple linear regression equation as follows: $Y$ $=0.414+0.997 X 1+0.866 X 2$, which can be interpreted as that the variables X1 and $X 2$ are zero $(0)$, then the variable $Y$ will be worth 0.414 units; if the direct compensation (X1) increases by one unit and the other variable is constant, then the $Y$ variable will increase by 0.997 units, and if the indirect compensation (X2) increases by one unit and the other variable is constant, then the $Y$ variable will increase by 0.866 units.

The conclusion of this study obtained the value of determination coefficient of $82.7 \%$ or the value of 0.827 which indicates the meaning that direct compensation (X1) and indirect compensation (X2) gives simultaneous effect of $82.7 \%$ on employee performance $(Y)$. While the rest of $17.3 \%$ influenced by other factors that ignored the author. The value of Adjusted R2 0.820 or the value of $82.0 \%$ indicating the meaning that, if there are other independent variables to be included, direct and indirect compensation variables, remain to have an effect of $82.0 \%$. Against employee performance.
\end{abstract}

Keywords: Direct Compensation, Indirect Compensation and Performance 


\section{PENDAHULUAN}

Sumber daya manusia merupakan faktor penunjang agar perusahaan tetap bertahan di dalam persaingan. Kompensasi memegang peranan penting dalam meningkatkan kinerja karyawan, salah satu alasan utama seseorang bekerja adalah untuk memenuhi kebutuhan hidupnya. Seseorang akan bekerja maksimal agar mendapatkan kompensasi yang sesuai dengan harapan. Kebijakan kompensasi selain memberikan imbalan kepada karyawan atas pekerjaan yang dilakukan karyawan juga merupakan salah satu cara untuk mempertahankan karyawan yang potensial.

Pemberian kompensasi dapat dilakukan dengan dua cara yaitu dengan cara pemberian kompensasi langsung yang langsung bisa dirasakan oleh karyawan. Kompensasi langsung ini bisa berupa gaji, upah, insentif dan lainnya. Adapun cara yang satunya adalah dengan pemberian kompensasi tidak langsung. Kompensasi ini biasanya berupa tunjangan-tunjangan dan fasilitas-fasilitas.

Kompensasi pada PT Pranata Jaya Abadi Banjaran pada bagian staff operasional baik kompensasi langsung maupun kompensasi tidak langsung dipandang oleh karyawan nya belum adil. Kompensasi langsung yang sejatinya merupakan balas jasa atas kinerja mereka tidak diberikan secara adil. Waktu lama kerja , jabatan kerja tidak ada perbedaan antara karyawan lama dan karyawan baru dalam hal pemberian gaji. Pemberian gaji sebagai bentuk dari kompensasi langsung, diberikan oleh perusahaan adalah sama rata sesuai dengan UMR (Upah minumum rata-rata) yang berlaku. Begitupun dengan hal pemberian kompensasi tidak langsung yang merupakan hak dari semua karyawan, fasililitas yang diberikan oleh perusahaan sama rata. Berikut adalah lama waktu kerja di PT Pranata Jaya Abadi Banjaran.

Tabel 1. Lama Waktu Kerja Karyawan PT Pranata Jaya Abadi Banjaran Bagian Staff operasional.

\begin{tabular}{|c|c|c|}
\hline No & $\begin{array}{c}\text { Lama Waktu } \\
\text { Kerja }\end{array}$ & Jumlah \\
\hline 1 & $3-4$ tahun & 21 orang \\
\hline 2 & $2-3$ tahun & 14 orang \\
\hline 3 & $1-2$ tahun & 17 orang \\
\hline 4 & $<1$ tahun & 6 orang \\
\hline \multicolumn{2}{|c|}{ Jumlah karyawan } & 58 orang \\
\hline
\end{tabular}

Sumber : PT Pranata Jaya Abadi, 2016

Tabel 1.1 memperlihatkan paling lama waktu kerja pada PT Pranata Jaya Abadi Banjaran Bagian Staff Operasional adalah 4 tahun. Berdasarkan wawancara yang dilakukan, Kompensasi langsung yang diberikan berupa gaji kepada ke 58 karyawan adalah sama, yang membedakan hanya ada pada pemberian lembur dan insentif bonus. 
PT Pranata Jaya Abadi adalah perusahaan yang bergerak dibidang Industri Textil jasa pencelupan kain dan pertenunan kain knitting, yang terletak di Jl Raya Banjaran KM 14,9 pameungpeuk Banjaran. Perusahaan ini memiliki pegawai tetap, kontrak, serta buruh harian. Untuk karyawan tetap berada pada bagian Staff Operasional yang berjumlah 58 orang. Perusahaan memberikan Kompensasi langsung sebagai balas jasa atas kinerja mereka. Sedangkan kompensasi tidak langsung merupakan kepedulian perusahaan untuk meningakatkan kesejahteraan karyawan nya yang tidak ada hubungan nya dengan pekerjaan (Hasibuan, 2012 :118). Kompensasi tidak langsung yang diberikan oleh perusahaan diharapkan dapat membangun loyalitas dari karyawannya. Berikut terlampir kompensasi langsung dan kompensasi tidak langsung yang telah diberikan oleh PT Pranata Jaya Abadi kepada Staff Bagian Operasional.
Tabel 1. Rincian Nominal Pemberian Kompensasi Langsung dan Kompensasi Tidak Langsung PT. Pranata jaya Abadi Banjaran Bagian Staff Operasional Tahun 2013-2015

\begin{tabular}{|c|c|c|c|c|}
\hline $\begin{array}{c}\text { Jenis } \\
\text { Kompe } \\
\text { nsasi }\end{array}$ & $\begin{array}{c}\text { Item } \\
\text { Kompensa } \\
\text { si }\end{array}$ & $\begin{array}{l}2013 \\
(\mathbf{R p})\end{array}$ & $\begin{array}{l}2014 \\
\text { (Rp) }\end{array}$ & $\begin{array}{l}2015 \\
\text { (Rp) }\end{array}$ \\
\hline \multirow{3}{*}{$\begin{array}{l}\text { Lang } \\
\text { sung }\end{array}$} & Gaji & $\begin{array}{r}1,097,874,0 \\
00\end{array}$ & $\begin{array}{r}1,264,140 \\
000\end{array}$ & $\begin{array}{r}1,353,800 \\
000\end{array}$ \\
\hline & Lembur & $63,940,800$ & $69,000,000$ & $42,320,000$ \\
\hline & $\begin{array}{l}\text { Bonus } \\
\text { Insentif }\end{array}$ & $47,955,600$ & $51,750,000$ & $24,954,000$ \\
\hline \multicolumn{2}{|r|}{ Jumlah } & $\begin{array}{r}1,161,814,8 \\
00\end{array}$ & $\begin{array}{r}1,384,890 \\
000\end{array}$ & $\begin{array}{r}1,421,074 \\
000\end{array}$ \\
\hline \multicolumn{2}{|r|}{ Persentase } & - & $\begin{array}{r}\text { Kenaikan } \\
19,20 \%\end{array}$ & $\begin{array}{r}\text { Kenaikan } \\
2,61 \%\end{array}$ \\
\hline \multirow[t]{3}{*}{$\begin{array}{l}\text { Tidak } \\
\text { Lang } \\
\text { sung }\end{array}$} & $\begin{array}{l}\text { Tunjanga } \\
\mathrm{n} \\
\text { Kesehata } \\
\mathrm{n}\end{array}$ & $\begin{array}{r}115,279,68 \\
0\end{array}$ & $\begin{array}{r}130,824,00 \\
0\end{array}$ & $\begin{array}{r}125,000,00 \\
0\end{array}$ \\
\hline & $\begin{array}{l}\text { Darmawi } \\
\text { sata }\end{array}$ & $\begin{array}{r}102,231,18 \\
0\end{array}$ & $\begin{array}{r}113,274,00 \\
0\end{array}$ & $50,000,000$ \\
\hline & $\begin{array}{l}\text { Tunjanga } \\
\mathrm{n} \quad \text { Hari } \\
\text { Raya }\end{array}$ & $79,704,000$ & $91,800,000$ & $\begin{array}{r}105,600,00 \\
0\end{array}$ \\
\hline \multicolumn{2}{|r|}{ Jumlah } & $\begin{array}{r}297,214,86 \\
0\end{array}$ & $\begin{array}{r}335,898,00 \\
0\end{array}$ & $\begin{array}{r}280,600,00 \\
0\end{array}$ \\
\hline \multicolumn{2}{|r|}{ Persentase } & - & $\begin{array}{r}\text { Kenaikan } \\
13,01 \%\end{array}$ & $\begin{array}{r}\text { Penurunan } \\
16,46 \%\end{array}$ \\
\hline \multicolumn{2}{|r|}{ TOTAL } & $\begin{array}{r}1,459,089,8 \\
60\end{array}$ & $\begin{array}{r}1,720,788 \\
000\end{array}$ & $\begin{array}{r}1,701,674,0 \\
00\end{array}$ \\
\hline \multicolumn{2}{|r|}{ Persentase } & - & $\begin{array}{r}\text { Kenaikan } \\
17,93 \%\end{array}$ & $\begin{array}{r}\text { Penurunan } \\
1,11 \%\end{array}$ \\
\hline
\end{tabular}

Sumber : PT Pranata Jaya Abadi Banjaran, data Sekunder yang diolah 2016.

Pada Tabel 1.2 memperlihatkan pemberian kompensasi langsung dan tidak langsung dari tahun 2013-2015. Pemberian 
kompensasi langsung mengalami kenaikan pada tahun 2014 cukup besar 19,20\% namun pada tahun 2015 hanya ada kenaikan sebesar $2,61 \%$ ada selisih sebesar $16.58 \%$ dibandingkan tahun 2014. Adapun pemberian kompensasi tidak langsung pada tahun 2014 meninggkat 13,01\% namun pada tahun 2015 terjadi penurunan sebesar 16,46\% . Dari total persentase keselurahan pemberian kompensasi langsung dan tidak langsung pada tahun 2014 meningkat 17,93\% namun pada tahun 2015 terjadi penurunan sebesar $1,11 \%$, hal tersebut dapat menjadi indikasi penyebab turun nya kinerja karyawan PT Pranata Jaya Abadi .

Kinerja karyawan merupakan hasil kerja secara kualitas dan kuantitas yang dicapai oleh seorang pegawai dalam melaksanakan tugasnya sesuai dengan tanggungj awab yang diberikan kepadanya (Mangkunegara, 2013:67).

Sebuah perusahaan bergantung terhadap kinerja baik karyawannya. Dalam pemberian kompensasi terkadang menimbulkan kecemburuan sosial antara pegawai satu dengan pegawail lainnya yang mempengaruhi kinerja karyawan. Jika pemberian kompensasi tersebut tidak adil akan mengakibatkan menurunya tingkat kinerja karyawan.

Kondisi tersebut akan mengakibatkan karyawan tidak produktif dalam bekerja dan pekerjaan akan sering selsai tidak tepat waktu. Hal ini sangat merugikan bagi perusahaan karena dirasa tidak efektif, efisien dan optimal.

Tabel 2. Nilai Kinerja Karawan Bagian Staff Operasional PT Pranata Jaya Abadi Berdasarkan Kompetensi yang telah di bobotkanTahun 2013-2015

\begin{tabular}{|c|c|c|c|c|}
\hline \multirow[b]{2}{*}{ Interval Nilai } & \multirow[b]{2}{*}{ Kategori } & \multicolumn{3}{|c|}{ Jumlah Pegawai } \\
\hline & & 2013 & 2014 & 2015 \\
\hline $0,00-20,00$ & Sangat jelek & 0 & 0 & 0 \\
\hline$>20,00-40,00$ & Jelek & 11 & 10 & 12 \\
\hline$>40,00-60,00$ & Cukup & 16 & 16 & 20 \\
\hline$>60,00-80,00$ & Baik & 16 & 15 & 12 \\
\hline$>80,00-100,00$ & Sangat Baik & 15 & 17 & 14 \\
\hline \multicolumn{2}{|c|}{ Jumlah } & 58 & 58 & 58 \\
\hline
\end{tabular}

Sumber : PT Pranata Jaya Abadi Banjaran, data Sekunder yang diolah 2016.

Pada tabel 1.3 kategori sangat baik tertingi adalah pada tahun 2014 dengan jumlah 17 orang dan terendah ada pada tahun 2015 dengan nilai 14 orang. Dan kategori jelek tertinggi ada pada tahun 2015 dengan jumlah 12 orang dan terendah ada pada tahun 2014 dengan jumlah 10 orang. Bobot kriteria berdasarkan dari kinerja yang telah dilakukan oleh para karyawan antara lain berdasarkan keterampilan teknis, pengetahuan, penyesuaian pekerjaan,kedisiplinan dan hubungan kerja dengan rekan sejawat.

Adapun Analisa tabel 1.2 dan tabel 1.3 sebagai berikut : 
1. Kategori karyawan dengan nilai jelek pada tahun 2013 sebanyak 11 orang, dan pada tahun 2014 jumlah kategori karyawan dengan nilai jelek berkurang menjadi 10 orang. Diindikasikan dari adanya kenaikan pemberian kompensasi sebanyak $17.93 \%$ pada tahun 2014.

2. Pada tahun 2015 kategori karyawan dengan nilai jelek bertambahan dari 10 orang menjadi 12 orang. Sedangkan kategori nilai sangat baik mengalami penurunan, dari berjumlah 17 orang menjadi 14 orang. Diindikasikan dari adanya penurunan pemberian kompensasi langsung maupun tidak langsung pada tahun 2015 sebesar $1,11 \%$.

Kasus ini mendandakan pemberian kompensasi sangat berpengaruh terhadap kinerja pegawai, karena dalam memberikan kompensasi yang adil dan benar akan meningkatkan kinerja karyawan untuk menyelsaikan pekerjaan dengan tepat waktu Abdul Ghoni ( 2014:4). Dalam hal ini juga diatur oleh UU.NO. 13/2013 tentang keternagakerjaan "Bahwa kesejahteraan pekerja atau buruh adalah pemenuhan kebutuhan dan atau keperluan yang bersifat jasmaniah dan rohaniah, baik di dalam maupun di luar hubungan kerja, yang secara langsung atau tidak langsung dapat mempertinggi kinerja karyawan dalam lingkungan kerja yang sehat dan aman”.
KERANGKA TEORITIS \& HIPOTESIS

\section{Kinerja Karyawan}

Kinerja merupakan istilah yang berasal dari kata Job Performance atau Actual Performance (prestasi kerja atau prestasi sesungguhnya dicapai seseorang). Kinerja karyawan adalah hasil kerja secara kualitas dan kuantitas oleh seorang pegawai dalam melaksanakan tugasnya sesuai dengan tanggung jawab yang diberikan kepadanya, Anwar Prabu (2013 : 67)

\section{Indikator Kinerja Karyawan}

Indikator untuk mengukur kinerja karyawan secara individu ada 5 indikator, yaitu Robbins (2013:260) :

1.Kualitas. Merupakan alat ukur dari persepsi karyawan terhadap kualitas pekerjaan yang dihasilkan serta kesempurnaan tugas terhadap keterampilan dan kemampuan karyawan.

2.Kuantitas. Merupakan jumlah yang dihasilkan dinyatakan dalam istilah seperti jumlah unit, jumlah siklus aktivitas yang diselesaikan.

3.Ketepatan waktu. Merupakan tingkat aktivitas diselesaikan pada awal waktu yang dinyatakan, dilihat dari sudut koordinasi dengan hasil output serta memaksimalkan waktu yang tersedia untuk aktivitas lain.

4.Efektivitas. Merupakan tingkat penggunaan sumber daya organisasi 
(tenaga, uang, teknologi, bahan baku) dimaksimalkan dengan maksud menaikkan hasil dari setiap unit dalam penggunaan sumber daya.

5.Kemandirian. Merupakan tingkat seorang karyawan yang nantinya akan dapat menjalankan fungsi komitmen kerja. Merupakan suatu tingkat dimana karyawan mempunyai komitmen kerja dengan instansi dan tanggung jawab karyawan terhadap kantor.

\section{Kompensasi}

Menurut William B. Werther dan Keith Davis dalam Anwar Parbu (2013: 83) mendefinisikan : "Kompensasi adalah apa yang seseorang karyawan terima sebagai balasan dari pekerjaan yang diberikan nya, baik upah per jam ataupun gaji periodik yang didesain dan dikelola oleh bagian personalia. Kompensasi (compensation) juga merupakan pemberian balas jasa langsung (direct) dan tidak langsung (indirect) berupa yang atau barang kepada karyawan sebagai balas jasa yang diberikan kepada perusahaan"

\section{Kompensasi langsung}

Menurut Hasibuan (2013 : 118) kompensasi langsung adalah : "Merupakan kompensasi yang diterima oleh karyawan yang mempunyai hubungan langsung dengan pekerjaan yaitu, dalam bentuk gaji, upah, dan upah insentif. Kompensasi langsung merupakan hak bagi karyawan dan menjadi kewajiban perusahaan untuk membayarnya".

Kompensasi langsung ini bisa berbentuk gaji, upah, upah insentif, maupun uang lembur. Berikut pengertiannya:

a. Gaji adalah balas jasa yang dibayar secara periodik kepada karyawan tetap serta mempunyai jaminan yang pasti. Maksudnya pekerja akan tetap dibayarkan walaupun pekerja tersebut tidak masuk kerja.

b. Upah adalah balas jasa yang dibayarkan kepada pekerja harian dengan berpedoman atas perjanjian yang disepakati membayarnya.

c. Upah Insentif adalah tambahan balas jasa yang diberikan kepada karyawan tertentu yang prestasinya di atas prestasi standar. Upah insentif ini merupakan alat yang dipergunakan pendukung prinsip adil dalam pemberian kompensasi.

d. Upah yang dibayarkan kepada karyawan dikarenakan karyawan yang melebihi jam kerja yang telah ditetapkan sebelumnya.

\section{Kompensasi tidak langsung}

Menurut Hasibuan (2013:118) kompensasi tidak langsung adalah :

"Merupakan kompensasi yang diterima oleh karyawan yang tidak mempunyai hubungan secara langsung dengan pekerjaanya antara 
lain, asuransi kesehatan, uang pensiun, pakaian dinas, kafetaria, mushola, olahraga, darmawisata. Kompensasi tidak langsung bisa berupa benefit servis dari perusahaan yang diberikan berdasarkan kebijakan perusahaan terhadap semua karyawan dalam usaha meningkatkan kesejahteraan mereka”. Nawawi (2013:316) menggolongkan kompensasi tidak langsung menjadi beberapa bagian yaitu:

1. Pembayaran upah untuk waktu tidak bekerja (time-off benefit), meliputi:

1) Istirahat on the job, terdiri dari:

a) Periode Istirahat

b) Periode makan

c) Periode waktu cuti

2) Hari-hari sakit

3) Liburan dan cuti

4) Alasan lain, misal kehamilan, kecelakaan, upacara pemakaman.

2. Perlindungan ekonomis terhadap bahaya, meliputi:

1) Jaminan pembayaran upah dalam jumlah tertentu selama suatu periode

2) Rencana-rencana pension

3) Tunjangan hari tua

4) Tunjangan pengobatan

5) Pembentukan koperasi atau yayasan yang mengelola kredit karyawan

3. Program pelayanan karyawan, meliputi:

1) Rekreasi

2) Kafetaria

3) Perumahan

4) Beasiswa pendidikan
5) Fasilitas pembelian

6) Konseling finansial dan legal

7) Aneka ragam pelayanan lain.

4. Pembayaran kompensasi yang ditetapkan secara legal. Kompensasi tidak langsung yang digunakan adalah perlindungan ekonomis terhadap bahaya berupa tunjangan kesehatan, bayaran di luar jam kerja (sakit, hari besar, cuti), dan program pelayanan karyawan berupa penyediaan fasilitas-fasilitas (kendaraan, sarana olahraga, sarana peribadatan) dengan alasan ketiga item tersebut sesuai dengan kondisi yang ada dalam perusahaan. Kompensasi tidak langsung diberikan pada karyawan dalam rangka menciptakan kondisi kerja yang menyenangkan, dan memberikan kepuasan pada karyawan sehingga diharapkan karyawan merasa nyaman bekerja dalam perusahaan.

Jadi kompensasi tidak langsung adalah balas jasa yang diberikan dalam bentuk pelayanan karyawan, karena diperlakukan sebagai upaya penciptaan kondisi dan lingkungan kerja yang menyenangkan.

\section{Hipotesis}

$\mathrm{H}_{1}=$ Ada pengaruh kompensasi langsung $\left(\mathrm{X}_{1}\right)$ terhadap kinerja karyawan $(\mathrm{Y})$ secara parsial. 
$\mathrm{H}_{2}=$ Ada pengaruh kompensasi tidak langsung $\left(\mathrm{X}_{2}\right)$ terhadap kinerja karyawan secara parsial.

$\mathrm{H}_{3}=$ Ada pengaruh kompensasi langsung $\left(\mathrm{X}_{1}\right)$ dan kompensasi tidak langsung $\left(\mathrm{X}_{2}\right)$ terhadap kinderja karyawan (Y) secara simultan.

\section{METODE PENELITIAN}

Metode dapat diartikan sebagai suatu cara kerja untuk untuk mencapai tujuan tertentu, agar dapat terkumpul data serta dapat mencapai tujuan penelitian itu sendiri. Sedangkan menurut Sugiyono (2013 : 4) metode penelitian dapat diartikan sebagai cara ilmiah, yang dilakukan untuk mendapatkan data yang objektif, valid, dan reliable, dengan tujuan untuk dapat ditemukan, dibuktikan, dan dikembangkan suatu pengetahuan untuk memahami, memecahkan dan mengantisipasi masalah.

\section{Kerangka Pemikiran}

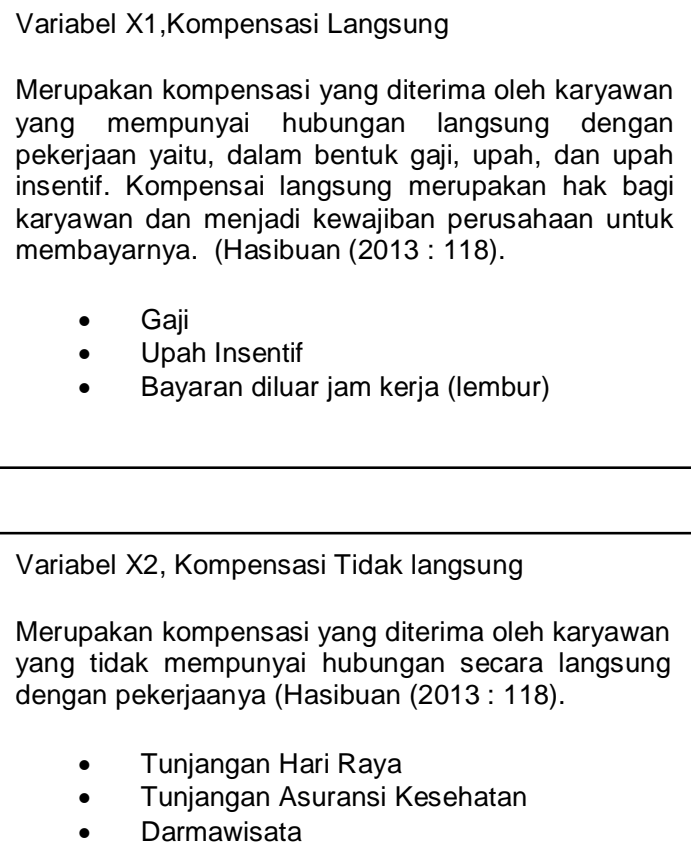

\section{Gambar 1. Kerangka Pemikiran}




\section{Metode Studi}

Berdasarkan variabel-variabel yang diteliti, maka metode penelitian yang digunakan dalam penelitian ini adalah metode deskriptif dan asosiatif. Penelitian deskriptif menurut Sugiyono (2013:35), Penelitian deskriptif adalah penelitian yang dilakukan untuk mengetahui nilai variabel mandiri dan tidak membuat perbandingan variabel dengan variabel lain Penelitian deskriptif disini bertujuan untuk memperoleh gambaran mengenai kompensasi langsung, kompensasi tidak langsung dan kinerja karyawan pada PT Pranata Jaya Abadi. Sedangkan Sedangkan metode penelitian asosiatif adalah penelitian yang bertujuan untuk mengetahui pengaruh ataupun juga hubungan antara dua variabel atau lebih.

\section{Identifikasi Variabel}

Variabel yang akan diukur dalam penelitian ini menggunakan dua variabel, sesuai dengan permasalahan yang sedang diteliti.

Kedua variabel tersebut adalah:

Variabel Terikat (Y)

Variabel terikat merupakan variabel yang besar kecilnya ditentukan oleh variabel bebas. Dalam penelitian ini variabel terikatnya adalah kinerja karyawan.

Variabel Bebas (X)

Variabel bebas merupakan variabel yang mempengaruhi terhadap variabel terikat.

Dalam penelitian ini variabel bebasnya adalah:
X1 : Kompensasi Langsung

X2 : Kompensasi Tidak Langsung

Populasi dan Teknik Pengambilan Sampel

Menurut Sugiyono (2013:80) populasi adalah wilayah generalisasi yang terdiri atas objek atau subjek yang mempunyai kualitas dan karakteristik tertentu yang ditetapkan oleh peneliti untuk dipelajari dan ditarik kesimpulannya.

Pada langkah awal seorang peneliti harus menentukan secara jelas mengnenai populasi yang menjadi sasaran penelitiannya yang disebut dengan populasi sasaran, yaitu populasi yang nantinya akan menjadi cakupan kesimpulan penelitian. Menurut etika penelitian, kesimpulan tersebut hanya berlaku untuk populasi sasaran yang telah ditentukan. Populasi dalam penelitian ini adalah seluruh karyawan PT Pranata Jaya Abadi bagian staff operasional sebanyak 58 orang.

Sedangkan sample adalah bagian dari jumlah dan karakteristik yang dimiliki populasi tersebut (Sugiyono, 2013:73). Pemilihan sampel dengan metode yang tepat dapat menggambarkan kondisi populasi yang sesungguhnya yang akurat dan dapat menghemat biaya penelitian secara efektif. Jumlah sample yang terlalu kecil dapat menyebabkan penelitian tidak dapat menggambarkan kondisi populasi yang 
sesungguhnya. Sebaliknya, sample yang berlaku besar dapat mengakibatkan pemborosan biaya penelitian.

Metode yang digunakan untuk pengambilan sampel menggunakan teknik penarikan sampling jenuh yaitu teknik penentuan sampel bila semua anggota populasi digunakan sebagai sampel, Sugiyono (2013:85). Hal ini dilakukan dikarenakan jumlah populasi relative kecil kurang dari 100. Teknik sampel ini membuat generalisasi dengan kesalahan yang sangat kecil. Istilah lain sampel jenuh adalah sensus, dimana semua anggota populasi dijadikan sampel. Objek sampel tersebut adalah tenaga kerja seluruh bagian operasional yang berjumlah 58 orang.

\section{ANALISIS DATA DAN PEMBAHASAN}

\section{Uji Asumsi Klasik}

Uji asumsi klasik ini digunakan dalam penelitian ini karena penelitian ini menguji tentang pengaruh dari variable, sehingga alat uji hipotesis menggunakan regresi.Uji ini terdiri atas Normalitas, Multikolinearitas dan Heterokedastisitas.

\section{Uji Normalitas}

Metode yang digunakan adalah pengujian secara visual dengan metode gambar normal Probability Plots dalam program SPSS yang membandingkan distribusi kumulatif dari distribusi normal. Pada prinsipnya normalitas dapat dideteksi dengan melihat penyebaran data (titik) pada sumbu diagonal dari grafik. Dasar pengambilan keputusan:

- Jika data menyebar di sekitar garis diagonal dan mengikuti arah garis diagonal menunjukkan pola distribusi normal, maka dapat disimpulkan bahwa model regresi memenuhi asumsi normalitas.

- Jika data menyebar jauh dari garis diagonal dan/atau tidak mengikuti arah garis diagonal tidak menunjukkan pola distribusi normal, maka dapat disimpulkan bahwa model regresi tidak memenuhi asumsi normalitas.

\section{Uji Multikolonieritas}

Uji multikolonieritas bertujuan untuk menguji apakah dalam model regresi ditemukan adanya korelasi antar variable bebas (independen). Untuk mendeteksi adanya atau tidaknya multikolonieritas didalam model regresi adalah dilihat dari

(1) nilai tolerance dan lawannya

(2) variance inflation factor (VIF).

\section{Uji Heterokedastisitas}

Uji heteroskedastisitas bertujuan untuk menguji apakah dalam model regresi terjadi ketidaksamaan variance dari residual satu pengamatan ke pengamatan yang lain.

Pendeteksian ada atau tidaknya heteroskedastisitas dapat dilakukan dengan 
melakukan "uji korelasi Rank Spearman antara variabel independen dengan residual regresi" (Gujarati dan Porter, 2010:290).

Kriteria pengambilan keputusan yaitu : Nilai signifikansi korelasi $>0,05(\alpha=5 \%)$, maka dapat disimpulkan tidak terjadi heteroskedastisitas

Nilai signifikansi korelasi $<0,05(\alpha=5 \%)$, maka dapat disimpulkan bahwa terjadi heteroskedastisitas.

\section{Pengujian Hipotesis}

Pengujian hipotesis dilakukan dengan menggunakan SPSS 13 dan alat ujinya berupa regresi linier berganda, sehingga dapat diketahui pengaruh anatara variable independen terhadap variabel dependen.

Berikut ini model persamaan regresi linier berganda :

$Y=a+b 1 . X 1+b 2 . X 2+e$

Keterangan:

$Y$ : kinerja karyawan

$a$ : konstanta

b1b2b3 : koefisien variabel bebas

$X 1$ : kompensasi langsung

$X 2$ : kompensasi tidak langsung

$e$ : variabel Pengganggu

Untuk mendapat gambaran mengenai karyawan yang menjadi responden, dilihat berdasarkan : jenis kelamin, usia, pendidikan, bidang departemen, masa kerja. Setelah melihat hasil penyebaran kuesioner sebanyak 58 responden, maka dapat diketahui gambaran umum karyawan PT Pranata Jaya Abadi Banjaran sebagai berikut :

- sebagian besar karyawan adalah laki-laki yang merupakan responden terbanyak sebesar $64,90 \%$ dan sisanya sebesar $35,10 \%$ adalah karyawan perempuan. Hal ini menunjukan bahwa karyawan PT Pranata Jaya Abadi bagian staff operasional rata-rata didominasi oleh lakilaki.

- responden yang berusia antara 20-25 tahun berjumlah 10 orang (17\%), 26-30 tahun berjumlah 8 orang (14\%), 31-35 tahun berjumlah 19 orang (33\%), 36-40 tahun berjumlah 15 orang (26\%), dan usia lebih dari 40 tahun adalah 6 orang (10\%). Hal ini menunjukkan sebagian besar karyawan PT Pranata Jaya Abadi bagian Staff Operasional anatara 31-35 tahun.

- sebagian besar karyawan PT Pranata Jaya Abadi bagian Staff Operasional berlatar belakang pendidikan D3 yaitu sebanyak 25 orang $(43 \%)$, pendidikan SMA yaitu sebanyak 15 orang (26\%), dan Sarjana $18 \%(31 \%)$.

- sebagian besar karyawan PT Pranata Jaya Abadi bagian Staff Operasional bahwa sebagian besar memiliki masa kerja 3-4 tahun yaitu sebanyak 21 orang (36\%), masa kerja 2-3 rahun 14 orang (24\%), masa kerja 1-2 tahun 17 orang (29\%) dan 
masa kerja kurang dari 1 tahun sebanyak 6 orang (29\%).

\section{Uji Validitas dan Reliabilitas}

Instrumen dikatakan valid apabila memiliki koefisien validitas diatas 0,3 dan dikatakan reliabel apabila memiliki koefisien reliabilitas diatas 0,70. Uji validitas dan reliabilitas kuesioner dilakukan terhadap 29 item pernyataan. hasil pengujian uji validitas, dimana semua item pernyataan untuk variabel $\mathrm{X}_{1}$ valid karena skor $\mathrm{r}$ hitung lebih besar jika dibandingkan dengan $r$ kritis yang bernilai 0.30. Dengan demikian, maka proses selanjutnya adalah melakukan pengujian relaibilitas.

Hasil uji realibilitas untuk variabel $\mathrm{X}_{1}$ juga menunjukkan hasil yang reliable, karena memiliki nilai Cronbachs's Alpha lebih dari 0,70 yang berarti semua item pernyataan adalah reliabel.

Hasil pengujian uji validitas, dimana semua item pernyataan untuk variabel $\mathrm{X}_{2}$ valid karena skor $r$ hitung lebih besar jika dibandingkan dengan $r$ kritis yang bernilai 0.30. Dengan demikian, maka proses selanjutnya adalah melakukan pengujian relaibilitas.

Hasil uji realibilitas untuk variabel $\mathrm{X}_{2}$ juga menunjukkan hasil yang reliable, karena memiliki nilai Cronbachs's Alpha lebih dari
0,70 yang berarti semua item pernyataan adalah reliabel.

Hasil pengujian uji validitas, dimana semua item pernyataan untuk variabel $\mathrm{Y}$ valid karena skor $r$ hitung lebih besar jika dibandingkan dengan $r$ kritis yang bernilai 0.30. Dengan demikian, maka proses selanjutnya adalah melakukan pengujian relaibilitas.

Hasil pengujian reliabilitas sebagaimana yang terangkum dalam tabel 4.10 diatas dapat diketahui bahwa variabel $\mathrm{Y}$ yang diteliti mempunyai nilai koefisien reliabilitas lebih besar dari 0,70. Hal ini berarti instrument pertanyaan penelitian adalah reliable (handal), sehingga butir-butir pertanyaan yang tersusun dalam angket dapat digunakan untuk penelitian selanjutnya.

\section{Deskripsi Variabel}

Berikut tanggapan responden atas butir-butir pertanyaan dalam kuisioner tentang kompensasi langsung, kompensasi tidak langsung dan kinerja karyawan :

\section{Kompensasi Langsung}

1. Tanggapan responden terhadap Gaji atau upah yang di terima sesuai dengan jabatan, sebanyak 4 responden $(6,9 \%)$ menyatakan sangat setuju, 16 responden $(27,6 \%)$ menyatakan setuju, 15 responden $(25,6 \%)$ menyatakan netral, 22 
responden $(37,9 \%)$ menyatakan tidak setuju, dan 1 responden $(1,7 \%)$ menyatakan tidak setuju. Jumlah responden yang paling tinggi dengan persentase $37,9 \%$ menyatakan tidak setuju terhadap Gaji atau upah yang di terima sesuai dengan jabatan.

2. Tanggapan responden terhadap Gaji atau upah yang diterima sesuai dengan tanggung jawab, sebanyak 4 responden $(6,9 \%)$ menyatakan sangat setuju, 17 responden $(29,3 \%)$ menyatakan setuju, 16 responden $(27,6 \%)$ menyatakan netral, 20 responden $(34,5 \%)$ menyatakan tidak setuju, dan 1 responden $(1,7 \%)$ menyatakan tidak setuju. Jumlah responden yang paling tinggi dengan persentase $34,5 \%$ menyatakan tidak setuju terhadap Gaji atau upah yang diterima sesuai dengan tanggung jawab.

3. Tanggapan responden terhadap Gaji atau upah yang diterima dapat memenuhi kebutuhan sehari-hari, sebanyak 5 responden $(8,6 \%)$ menyatakan sangat setuju, 22 responden $(37,9 \%)$ menyatakan setuju, 19 responden $(32,8 \%)$ menyatakan netral, 12 responden $(20,7 \%)$ menyatakan tidak setuju, dan 0 responden $(0 \%)$ menyatakan tidak setuju. Jumlah responden yang paling tinggi dengan persentase $37,9 \% \%$ menyatakan setuju terhadap Gaji atau upah yang diterima dapat memenuhi kebutuhan sehari-hari.
4. Tanggapan responden terhadap Gaji atau upah yang diterima sesuai dengan lamanya bekerja, sebanyak 3 responden $(5,2 \%)$ menyatakan sangat setuju, 28 responden $(48,3 \%)$ menyatakan setuju, 13 responden $(22,4 \%)$ menyatakan netral, 14 responden $(24,1 \%)$ menyatakan tidak setuju, dan 0 responden $(0 \%)$ menyatakan tidak setuju. Jumlah responden yang paling tinggi dengan persentase $48,3 \% \%$ menyatakan setuju terhadap Gaji atau upah yang diterima sesuai dengan lamanya bekerja.

5. Tanggapan responden terhadap Pembayaran jam lembur yang didapatkan sesuai dengan perjanjian, sebanyak 4 responden $(6,9 \%)$ menyatakan sangat setuju, 17 responden $(29,3 \%)$ menyatakan setuju, 16 responden (27,6\%) menyatakan netral, 21 responden $(36,2 \%)$ menyatakan tidak setuju, dan 0 responden $(0 \%)$ menyatakan tidak setuju. Jumlah responden yang paling tinggi dengan persentase $36,2 \%$ menyatakan tidak setuju terhadap Pembayaran jam lembur yang didapatkan sesuai dengan perjanjian.

6. Tanggapan responden terhadap kewajiban lembur yang diterapkan perusahaan terasa berlebihan / memberatkan, sebanyak 2 responden $(3,4 \%)$ menyatakan sangat setuju, 19 responden $(32,8 \%)$ menyatakan setuju, 24 responden $(41,4 \%)$ menyatakan netral, 
12 responden $(20,7 \%)$ menyatakan tidak setuju, dan 1 responden $(1,7 \%)$ menyatakan tidak setuju. Jumlah responden yang paling tinggi dengan persentase $41,4 \%$ menyatakan netral terhadap terhadap kewajiban lembur yang diterapkan perusahaan terasa berlebihan / memberatkan.

7. Tanggapan responden terhadap Bonus insentif yang diterima menambah semangat kerja, sebanyak 3 responden $(5,2 \%)$ menyatakan sangat setuju, 25 responden $(43,1 \%)$ menyatakan setuju, 17 responden $(29,3 \%)$ menyatakan netral, 13 responden $(22,4 \%)$ menyatakan tidak setuju, dan 0 responden $(0 \%)$ menyatakan tidak setuju. Jumlah responden yang paling tinggi dengan persentase $43,1 \%$ menyatakan setuju terhadap terhadap Bonus insentif yang diterima menambah semangat kerja,.

8. Tanggapan responden terhadap Bonus insentif yang diterima sesuai atas kinerja, sebanyak 3 responden $\quad(5,2 \%)$ menyatakan sangat setuju, 26 responden $(44,8 \%)$ menyatakan setuju, 20 responden $(34,5 \%)$ menyatakan netral, 9 responden $(15,5 \%)$ menyatakan tidak setuju, dan 0 responden $(0 \%)$ menyatakan tidak setuju. Jumlah responden yang paling tinggi dengan persentase $44,81 \%$ menyatakan setuju terhadap Bonus insentif yang diterima sesuai atas kinerja.
9. Tanggapan responden terhadap Bonus insentif yang diberikan secara adil dan merata sesuai dengan peraturan perusahaan, sebanyak 3 responden $(5,2 \%)$ menyatakan sangat setuju, 30 responden $(51,7 \%)$ menyatakan setuju, 13 responden (22.4\%) menyatakan netral, 11 responden $(19,0 \%)$ menyatakan tidak setuju, dan 1 responden $(1,7 \%)$ menyatakan tidak setuju. Jumlah responden yang paling tinggi dengan persentase $51,7 \%$ menyatakan setuju terhadap Bonus insentif yang diberikan secara adil dan merata sesuai dengan peraturan perusahaan.

10. Hasil penelitian menunjukkan skor dari responden terhadap pemberian kompensasi langsung. Diketahui bahwa skor tertinggi adalah 221 atau sebesar $12,8 \%$ yang berhubungan dengan bonus insentif yang diterima menambah semangat kerja. Sedangkan skor terkecil adalah 174 atau sebesar $10,1 \%$ yang berhubungan dengan gaji atau upah yang diterima sesuai dengan jabatan.

\section{Kompensasi Tidak Langsung}

1. Tanggapan responden terhadap THR yang didapatkan sesuai dengan peraturan pemerintah, sebanyak 4 responden $(6,9 \%)$ menyatakan sangat setuju, 18 responden $(31,0 \%)$ menyatakan setuju, 15 responden $(25,9 \%)$ menyatakan netral, 21 responden $(36,2 \%)$ menyatakan tidak 
setuju, dan 0 responden (0\%) menyatakan tidak setuju. Jumlah responden yang paling tinggi dengan persentase $36,2 \%$ menyatakan tidak setuju terhadap THR yang didapatkan sesuai dengan peraturan pemerintah.

2. Tanggapan responden terhadap THR yang didapatkan meringankan beban pengeluaran saat hari raya, sebanyak 3 responden $(5,2 \%)$ menyatakan sangat setuju, 20 responden $\quad(34,5 \%)$ menyatakan setuju, 20 responden $(34,5 \%)$ menyatakan netral, 15 responden (25,9\%) menyatakan tidak setuju, dan 0 responden $(0 \%)$ menyatakan tidak setuju. Jumlah responden yang paling tinggi dengan persentase $36,2 \%$ menyatakan tidak setuju terhadap THR yang didapatkan sesuai dengan peraturan pemerintah

3. Tanggapan responden terhadap Asuransi kesehatan yang diberikan dapat memadai, sebanyak 2 responden $(3,4 \%)$ menyatakan sangat setuju, 19 responden $(32,8 \%)$ menyatakan setuju, 24 responden $(41,4 \%)$ menyatakan netral, 12 responden $(20,7 \%)$ menyatakan tidak setuju, dan 1 responden $(1,7 \%)$ menyatakan tidak setuju. Jumlah responden yang paling tinggi dengan persentase $46,6 \%$ menyatakan tidak setuju terhadap Asuransi kesehatan yang diberikan dapat memadai.
4. Tanggapan responden terhadap Asuransi kesehatan yang diberikan memberikan rasa aman, sebanyak 4 responden $(6,9 \%)$ menyatakan sangat setuju, 21 responden $(36,2 \%)$ menyatakan setuju, 6 responden $(10,3 \%)$ menyatakan netral, 27 responden $(46,6 \%)$ menyatakan tidak setuju, dan 0 responden $(0 \%)$ menyatakan tidak setuju. Jumlah responden yang paling tinggi dengan persentase $43,1 \%$ menyatakan tidak setuju terhadap Asuransi kesehatan yang diberikan memberikan rasa aman.

5. Tanggapan responden terhadap Darmawisata membuat mejadi lebih kompak dengan sesama karyawan, sebanyak 4 responden $\quad(6,9 \%)$ menyatakan sangat setuju, 19 responden $(32,8 \%)$ menyatakan setuju, 10 responden $(17,2 \%)$ menyatakan netral, 25 responden $(43,1 \%)$ menyatakan tidak setuju, dan 0 responden $(0 \%)$ menyatakan tidak setuju. Jumlah responden yang paling tinggi dengan persentase $48,3 \%$ menyatakan tidak setuju terhadap Asuransi kesehatan yang diberikan memberikan rasa aman.

6. Tanggapan responden terhadap Darmawisata membuat menjadi lebih bersemangat dalam bekerja, sebanyak 2 responden $(3,4 \%)$ menyatakan sangat setuju, 11 responden $(19,0 \%)$ menyatakan setuju, 17 responden $(17,2 \%)$ menyatakan netral, 25 responden 
$(43,1 \%)$ menyatakan tidak setuju, dan 0 responden $(0 \%)$ menyatakan tidak setuju.

7. Hasil penelitian menunjukkan skor dari responden terhadap pemberian kompensasi tidak langsung. Diketahui bahwa skor tertinggi adalah 185 atau sebesar 17,4\% yang berhubungan asuransi yang diberikan memadai. Sedangkan skor terkecil adalah 161 atau sebesar $15,1 \%$ yang berhubungan dengan darmawisata membuat menjadi lebih bersemangat dalam bekerja.

\section{Kinerja Karyawan}

1. Tanggapan responden terhadap Tingkat pencapaian volume kerja yang di hasilkan sesuai dengan harapan perusahaan, sebanyak 4 responden $(6,9 \%)$ menyatakan sangat setuju, 20 responden $(34,5 \%)$ menyatakan setuju, 14 responden $(24,12 \%)$ menyatakan netral, 20 responden $(34,5 \%)$ menyatakan tidak setuju, dan 0 responden $(0 \%)$ menyatakan tidak setuju. Jumlah responden yang paling tinggi dengan persentase $34,5 \%$ menyatakan setuju dan $34,5 \%$ menyatakan tidak setujuTingkat pencapaian volume kerja yang di hasilkan sesuai dengan harapan perusahaan.

2. Tanggapan responden terhadap Kemampuan yang saya miliki sesuai dengan pekerjaan yang saya kerjakan, sebanyak 5 responden $(8,6 \%)$ menyatakan sangat setuju, 15 responden $(25,9 \%)$ menyatakan setuju, 26 responden $(44,8 \%)$ menyatakan netral, 12 responden $(20,7 \%)$ menyatakan tidak setuju, dan 0 responden $(0 \%)$ menyatakan tidak setuju. Jumlah responden yang paling tinggi dengan persentase 44,8\% menyatakan netral terhadap Kemampuan yang saya miliki sesuai dengan pekerjaan yang saya kerjakan.

3. Tanggapan responden terhadap mengerjakan suatu pekerjaan dengan penuh ketelitian, sebanyak 3 responden $(5,2 \%)$ menyatakan sangat setuju, 31 responden $(53,4 \%)$ menyatakan setuju, 11 responden $(19,0 \%)$ menyatakan netral, 13 responden $(22,4 \%)$ menyatakan tidak setuju, dan 0 responden $(0 \%)$ menyatakan tidak setuju.Jumlah responden yang paling tinggi dengan persentase $53,4 \%$ menyatakan setuju terhadap mengerjakan suatu pekerjaan dengan penuh ketelitian.

4. Tanggapan responden terhadap pengetahuan yang dimiliki, mampu melaksanakan pekerjaan dengan baik, sebanyak 3 responden $(5,2 \%)$ menyatakan sangat setuju, 17 responden $(29,3 \%)$ menyatakan setuju, 28 responden $(48,3 \%)$ menyatakan netral, 10 responden $(17,2 \%)$ menyatakan tidak setuju, dan 0 responden $(0 \%)$ menyatakan tidak setuju.Jumlah responden yang paling tinggi dengan persentase 48,3\% 
menyatakan netral terhadap pengetahuan yang dimiliki, mampu melaksanakan pekerjaan dengan baik.

5. Tanggapan responden terhadap pengetahuan yang dimiliki, membuat lebih menguasai bidang tugas yang dikerjakan, sebanyak 3 responden $(5,2 \%)$ menyatakan sangat setuju, 23 responden $(39,7 \%)$ menyatakan setuju, 20 responden $(34,5 \%)$ menyatakan netral, 12 responden $(20,7 \%)$ menyatakan tidak setuju, dan 0 responden $(0 \%)$ menyatakan tidak setuju. Jumlah responden yang paling tinggi dengan persentase 48,3\% menyatakan netral terhadap pengetahuan yang dimiliki, membuat lebih menguasai bidang tugas yang dikerjakan.

6. Tanggapan responden terhadap pengetahuan yang dimilki dapat menguasai bidang tugas departemen lain, sebanyak 2 responden $(3,4 \%)$ menyatakan sangat setuju, 23 responden $(37,9 \%)$ menyatakan setuju, 14 responden $(24,1 \%)$ menyatakan netral, 18 responden $(9,0 \%)$ menyatakan tidak setuju, dan 1 responden $(1,7 \%)$ menyatakan tidak setuju. Jumlah responden yang paling tinggi dengan persentase $39,7 \%$ menyatakan setuju terhadap pengetahuan yang dimilki dapat menguasai bidang tugas departemen lain.

7. Tanggapan responden terhadap mendahulukan pekerjaan-pekerjaan yang merupakan prioritas kerja, sebanyak 5 responden $(8,6 \%)$ menyatakan sangat setuju, 16 responden menyatakan setuju, 17 responden $(29,3 \%)$ menyatakan netral, 20 responden $(34,5 \%)$ menyatakan tidak setuju, dan 0 responden $(0 \%)$ menyatakan tidak setuju.Jumlah responden yang paling tinggi dengan persentase $34,5 \%$ menyatakan tidak setuju terhadap mendahulukan pekerjaan-pekerjaan yang merupakan prioritas kerja.

8. Tanggapan responden terhadap Untuk menghasilkan suatu pekerjaan yang praktis,harus proaktif didalam mencari tata kinerja baru, sebanyak 5 responden $(8,6 \%)$ menyatakan sangat setuju, 21 responden $(36,2 \%)$ menyatakan setuju, 11 responden $(19,0 \%)$ menyatakan netral, 21 responden $(36,2 \%)$ menyatakan tidak setuju, dan 0 responden $(0 \%)$ menyatakan tidak setuju.Jumlah responden yang paling tinggi dengan persentase $36,2 \%$ setuju dan $36,2 \%$ tidak setuju terhadap Untuk menghasilkan suatu pekerjaan yang praktis,harus proaktif didalam mencari tata kinerja baru.

9. Tanggapan responden terhadap cepat menyesuaikan diri pada setiap keputusankeputusan baru yang diambil perusahaan, sebanyak 5 responden $(8,6 \%)$ menyatakan sangat setuju, 15 responden $(25,9 \%)$ menyatakan setuju, 27 responden $(46,6 \%)$ menyatakan netral, 11 
responden $(19,0 \%)$ menyatakan tidak setuju, dan 0 responden $(0 \%)$ menyatakan tidak setuju..Jumlah responden yang paling tinggi dengan persentase 46,6\% netral terhadap cepat menyesuaikan diri pada setiap keputusan-keputusan baru yang diambil perusahaan.

10. Tanggapan responden terhadap mematuhi segala peraturan yang ada diperusahaan, sebanyak 5 responden $(8,6 \%)$ menyatakan sangat setuju, 22 responden $(37,9 \%)$ menyatakan setuju, 19 responden $(32,8 \%)$ menyatakan netral, 12 responden $(30,7 \%)$ menyatakan tidak setuju, dan 0 responden $(0 \%)$ menyatakan tidak setuju.Jumlah responden yang paling tinggi dengan persentase $37,9 \%$ setuju terhadap mematuhi segala peraturan yang ada diperusahaan.

11. Tanggapan responden terhadap jam masuk dan pulang kerja sesuai dengan peraturan perusahaan, sebanyak 5 responden $(8,6 \%)$ menyatakan sangat setuju, 24 responden $(41,4 \%)$ menyatakan setuju, 17 responden (29,3\%) menyatakan netral, 12 responden $(30,7 \%)$ menyatakan tidak setuju, dan 0 responden $(0 \%)$ menyatakan tidak setuju.Jumlah responden yang paling tinggi dengan persentase $41,4 \%$ setuju terhadap mematuhi segala peraturan yang ada diperusahaan.
12. Tanggapan responden terhadap bekerja sesuai dengan koridor stuktur organisasi perusahaan, sebanyak 3 responden $(5,2 \%)$ menyatakan sangat setuju, 32 responden $(55,2 \%)$ menyatakan setuju, 12 responden $(20,7 \%)$ menyatakan netral, 11 responden $(19,0 \%)$ menyatakan tidak setuju, dan 0 responden (0\%) menyatakan tidak setuju.Jumlah responden yang paling tinggi dengan persentase $55,2 \%$ setuju terhadap bekerja sesuai dengan koridor stuktur organisasi perusahaan.

13. Tanggapan responden terhadap memegang erat sistem pendelegasian wewenang, tugas dan tanggung jawab yang ditetapkan perusahaan, sebanyak 6 responden $(10,3 \%)$ menyatakan sangat setuju, 22 responden $(37,9 \%)$ menyatakan setuju, 18 responden $(31,0 \%)$ menyatakan netral, 12 responden $(20,7 \%)$ menyatakan tidak setuju, dan 0 responden (0\%) menyatakan tidak setuju.Jumlah responden yang paling tinggi dengan persentase $37,9 \%$ setuju terhadap memegang erat sistem pendelegasian wewenang, tugas dan tanggung jawab yang ditetapkan perusahaan.

14. Tanggapan responden terhadap dapat bekerja dengan baik dengan sesama rekan, sebanyak 3 responden $(5,2 \%)$ menyatakan sangat setuju, 23 responden $(39,7 \%)$ menyatakan setuju, 23 
responden $(39,7 \%)$ menyatakan netral, 18 responden $(13,8 \%)$ menyatakan tidak setuju, dan 0 responden $(0 \%)$ menyatakan tidak setuju. Jumlah responden yang paling tinggi dengan persentase $39,7 \%$ setuju dan 39,7 netral terhadap dapat bekerja dengan baik dengan sesama rekan.

15. Hasil penelitian menunjukkan skor dari responden terhadap kinerja karyawan . Diketahui bahwa skor tertinggi adalah 201 atau sebesar 7,5\% yang berhubungan dengan bekerja sesuai dengan koridor stuktur organisasi perusahaan. Sedangkan skor terkecil adalah 180 atau sebesar $6,7 \%$ yang berhubungan dengan mendahulukan pekerjaan-pekerjaan yang merupakan prioritas kerja.

\section{Uji Asumsi Klasik}

\section{Uji Normalitas}

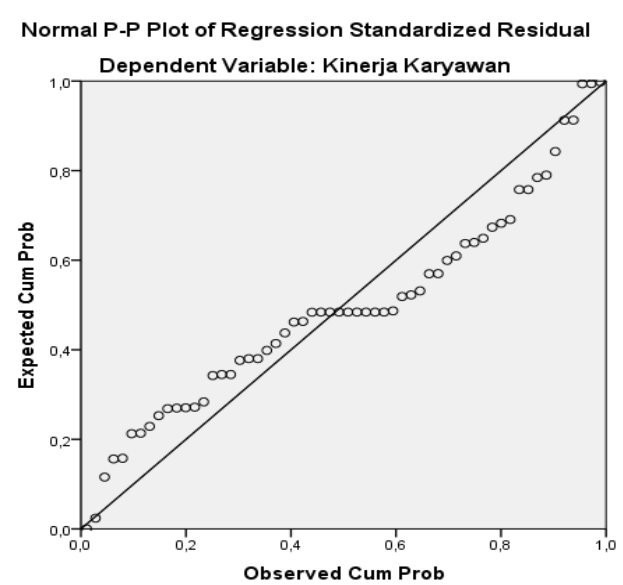

Gambar 2. Uji Normalitas
Berdasarkan pada normal p-plot residual terlihat bahwa residual berdistribusi secara normal. Hal ini terlihat dari data yang menyebar dekat dari diagonal atau mengikuti arah garis diagonal. Jadi dapat disimpulkan model regresi memenuhi asumsi normalitas residual.

\section{Uji Multikolonieritas}

Dengan menggunakan program SPSS 22.0 for Windows, didapat output nilai VIF untuk masing-masing variabel bebas sebagai berikut :

Coefficients $^{\mathrm{a}}$

\begin{tabular}{|ll|r|r|}
\hline \multirow{2}{*}{ Model } & \multicolumn{2}{|c|}{ Collinearity Statistics } \\
\cline { 3 - 4 } & & Tolerance & \multicolumn{1}{c|}{ VIF } \\
\hline 1 & Kompensasi Langsung &, 388 & 2,578 \\
& Kompensasi Tidak Langsung &, 388 & 2,578 \\
\hline
\end{tabular}

a. Dependent Variable: Kinerja Karyawan

\section{Gambar 3. Uji Multikolonieritas}

Hasil diatas menunjukkan bahwa nilai VIF masing-masing variabel bebas jauh di bawah 10, yakni $X_{1}=2,578$ dan $X_{2}=2,578$. Maka dapat disimpulkan bahwa tidak terdapat multikolinieritas antar variabel bebas dalam model regresi.

\section{Uji Heterokedastisitas}

Hasil penelitian menunjukkan bahwa titiktitik menyebar dan dan tidak membentuk sebuah pola serta sebarannya berada diatas dan dibawah titik nol. Dengan demikian dapat diketahui bahwa tidak terdapat 
pelanggaran asumsi heteroskedastisitas pada model regresi.

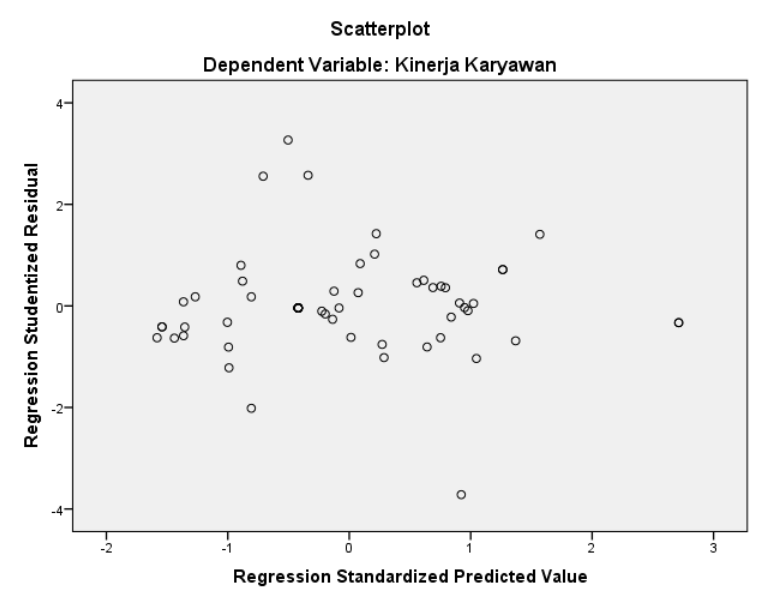

\section{Gambar 4. Uji Heterokedastisitas}

\section{Uji Hipotesis}

Dengan menggunakan SPSS diperoleh hasil koefisien regresi sebagai berikut :

\begin{tabular}{|c|c|c|c|c|c|c|}
\hline \multicolumn{7}{|c|}{ Coefficients $^{\mathrm{a}}$} \\
\hline \multirow[b]{2}{*}{ Model } & & \multicolumn{2}{|c|}{ Unstandardized Coefficients } & $\begin{array}{l}\text { Standardized } \\
\text { Coefficients }\end{array}$ & \multirow[b]{2}{*}{$t$} & \multirow[b]{2}{*}{ Sig. } \\
\hline & & B & Std. Error & Beta & & \\
\hline 1 & (Constant) & .414 & 2,953 & &, 140 &, 889 \\
\hline & Kompensasi Langsung & 997 &, 151 & .596 & 6,616 &, 000 \\
\hline & Kompensasi Tidak Langsung & .866 & .215 & 364 & 4,034 &, 000 \\
\hline
\end{tabular}

\section{Gambar 5. koefisien regresi}

Dari output di atas diketahui nilai kontstanta dan koefisien regresi sehingga dapat dibentuk persamaan regresi linier berganda sebagai berikut:

$Y=0,414+0,997 X_{1}+0,866 X_{2}$

Persamaan di atas dapat diartikan sebagai berikut:

$\mathrm{b}_{0}=0,414$ artinya jika variabel $\mathrm{X}_{1}$ dan $\mathrm{X}_{2}$ bernilai nol (0), maka variabel Y akan bernilai 0,414 satuan.

$\mathrm{b}_{1}=0,997 \quad$ artinya jika kompensasi langsung $\left(\mathrm{X}_{1}\right)$ meningkat sebesar satu satuan dan variabel lainnya konstan, maka variabel $\mathrm{Y}$ akan meningkat sebesar 0,997 satuan.

$\mathrm{b}_{2}=0,866 \quad$ artinya jika kompensasi tidak langsung $\left(\mathrm{X}_{2}\right)$ meningkat sebesar satu satuan dan variabel lainnya konstan, maka variabel $\mathrm{Y}$ akan meningkat sebesar 0,866 satuan.

\section{Korelasi Berganda}

\begin{tabular}{|c|c|r|r|c|}
\hline Model Summary \\
\hline 1 & $R$ & R Square & $\begin{array}{c}\text { Adjusted R } \\
\text { Square }\end{array}$ & $\begin{array}{c}\text { Std. Error of } \\
\text { the Estimate }\end{array}$ \\
\hline \multicolumn{4}{|c|}{ a. Predictors: (Constant), Kompensasi Tidak Langsung, } \\
Kompensasi Langsung \\
b. Dependent Variable: Kinerja Karyawan
\end{tabular}
b.

\section{Gambar 6. Uji Korelasi}

Dasar analisis diatas maka didapat 0,909 yang termasuk kedalam korelasi sangat kuat. Korelasi yang terjadi adalah korelasi positif, yaitu berada diantara $0,800-1,000$. Adapun dengan melihat Adjusted $R$ Square adalah nilai $\mathrm{R}^{2} \quad(\mathrm{R}$ square) yang telah disesuaikan, nilai ini selalu lebih kecil dari $\mathrm{R}^{2}$ dan angka ini bisa memiliki harga negatif. Interpretasinya sama dengan $\mathrm{R}$ Square, akan tetapi nilai Adjusted R Square 
dapat naik atau turun dengan adanya penambahan variabel baru, tergantung dari korelasi antara variabel bebas tambahan tersebut dengan variabel terikatnya. Nilai Adjusted R Square dapat bernilai negatif, sehingga jika nilainya negatif, maka nilai tersebut dianggap 0 , atau variabel bebas sama sekali tidak mampu menjelaskan varians dari variabel terikatnya.

\section{Koefisien Determinasi}

Setelah diketahui nilai Adjusted $\mathrm{R}^{2}$ sebesar 0,909, maka koefisien determinasi dapat dihitung menggunakan rumus sebagai berikut:

$$
\begin{aligned}
\mathrm{KD} & =\mathrm{R}^{2} \times 100 \% \\
& =(0,909)^{2} \times 100 \% \\
& =82,7 \%
\end{aligned}
$$

Dengan demikian, maka diperoleh nilai $\mathrm{KD}$ sebesar $82,7 \%$ atau nilai 0,827 yang menunjukkan arti bahwa kompensasi langsung $\left(\mathrm{X}_{1}\right)$ dan kompensasi tidak langsung $\left(\mathrm{X}_{2}\right)$ memberikan pengaruh simultan (bersama-sama) sebesar $82,7 \%$ terhadap kinerja karyawan (Y). Sedangkan sisanya sebesar $17,3 \%$ dipengaruhi oleh faktor lain yang diabaikan penulis. Adapun nilai Adjusted $\mathrm{R}^{2} \quad 0,820$ atau nilai sebesar 82,0\% yang menunjukkan arti bahwa, bila ada variabel bebas lain yang akan dimasukkan, variabel kompensasi langsung dan tidak langsung, tetap berpengaruh sebesar 82,0\%. Terhadap kinerja karyawan.

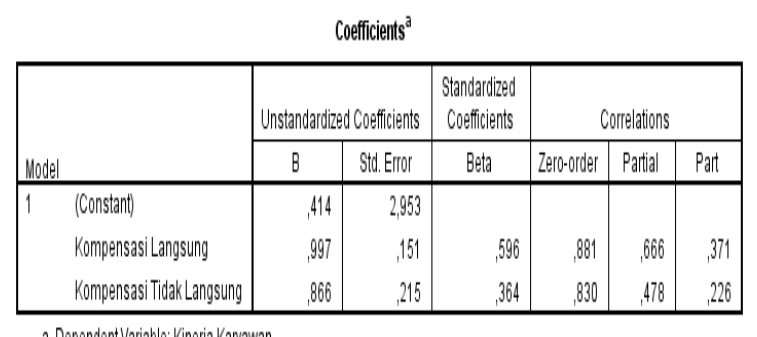

a. Dependent Variable: Kinerja Kanvawan

\section{Gambar 7. Uji}

Koefisien Beta $\mathrm{x}$ Zero-order :

1. Variabel $\mathrm{X}_{1}=0,596 \times 0,881=0,5250=$ $52,50 \%$

2. Variabel $\mathrm{X}_{2}=0,364 \times 0,830=0,3017=$ $30,17 \%$

Dari hasil uji individu diketahui bahwa variabel $\mathrm{X}_{1}$ (kompensasi langsung) terhadap variabel Y (kinerja karyawan) memiliki pengaruh positif sebesar $52,50 \%$. Sedangkan $\mathrm{X}_{2}$ (kompensasi tidak langsung) terhadap variabel $\mathrm{Y}$ (kinerja karyawan) memiliki pengaruh positif sebesar $30,17 \%$.

\begin{tabular}{|c|c|c|c|c|c|c|}
\hline \multicolumn{7}{|c|}{ Coefficients $^{\mathrm{a}}$} \\
\hline \multirow[b]{2}{*}{ Model } & & \multicolumn{2}{|c|}{ Unstandardized Coefficients } & \multirow{2}{*}{$\begin{array}{c}\begin{array}{c}\text { Standardized } \\
\text { Coefficients }\end{array} \\
\text { Beta }\end{array}$} & \multirow[b]{2}{*}{$t$} & \multirow[b]{2}{*}{ Sig. } \\
\hline & & $B$ & Std. Error & & & \\
\hline 1 & (Constant) & .414 & 2,953 & &, 140 & 889 \\
\hline & Kompensasi Langsung &, 997 &, 151 &, 596 & 6,616 &, 000 \\
\hline & Kompensasi Tidak Langsung &, 866 & .215 &, 364 & 4,034 &, 000 \\
\hline
\end{tabular}

\section{Pengujian Hipotesis}

\section{Hipotesis Parsial (Uji-t)}

\section{Gambar 8. Uji-t}

Dari output SPSS diperoleh nilai thitung untuk $\mathrm{X}_{1}$ sebesar 6,616 dan $\mathrm{t}_{\text {tabel }} 2,004$. Dikarenakan nilai $t_{\text {hitung }}>t_{\text {tabel, }}$ maka Hoditolak, artinya variabel kompensasi 
langsung berpengaruh signifikan terhadap variabel kinerja karyawan.

\section{Hipotesis Simultan (Uji-F)}

\begin{tabular}{|c|c|c|c|c|c|c|}
\hline \multicolumn{7}{|c|}{ ANOVA $^{\mathrm{a}}$} \\
\hline \multicolumn{2}{|c|}{ Model } & $\begin{array}{l}\text { Sum of } \\
\text { Squares }\end{array}$ & df & Mean Square & $\mathrm{F}$ & Sig. \\
\hline \multirow[t]{3}{*}{1} & Regression & 6318,124 & 2 & 3159,062 & 131,237 &, $000^{\mathrm{b}}$ \\
\hline & Residual & 1323,926 & 55 & 24,071 & & \\
\hline & Total & 7642,051 & 57 & & & \\
\hline
\end{tabular}

\section{Gambar 9. Uji-F}

Berdasarkan output diketahui nilai $\mathrm{F}_{\text {hitung }}$ sebesar 131,237 dengan p-value (sig) 0,000. Dengan $\alpha=0,05$ serta derajat kebebasan $\mathrm{v}_{1}=$ 55 dan $\mathrm{v}_{2}=2$, maka di dapat $\mathrm{F}_{\text {tabel }} 3,165$. Dikarenakan nilai $\quad F_{\text {hitung }}>\quad F_{\text {tabel }}$ $(131,237>3,165)$ maka $\mathrm{H}_{0}$ ditolak, artinya variabel bebas secara simultan variabel kompensasi langsung $\left(\mathrm{X}_{1}\right)$ dan kompensasi tidak langsung $\left(\mathrm{X}_{2}\right)$ berpengaruh signifikan terhadap kinerja karyawan (Y).

\section{SIMPULAN DAN SARAN}

Pemberian kompensasi langsung di PT Pranata Jaya Abadi terhadap karyawan bagian staff operasional yang telah dilaksanakan cukup baik. Bonus sebagai kompensasi langsung, membuat para karyawan menjadi semangat bekerja. Karyawann puas dengan bonus yang diberikan oleh perusahaan. Dapat memotivasi karyawan berkinerja baik secara berkesinambungan. Pemberian kompensasi tidak langusung di PT Pranata Jaya Abadi terhadap karyawan bagian staff operasional yang telah dilaksanakan cukup baik. Asuransi yang menmadai membuat para karyawan menjadi tenang dalam bekerja. Tentunya bekerja menjadi lebih fokus dan kinerja karyawan pun akan lebih baik. Kinerja karyawan bagian staff operasionadi PT Pranata Jaya Abadi yang telah dilaksanakan cukup baik. Karyawan di PT Pranata Jaya Abadi Banjaran bekerja sesuai dengan koridor segala aturan yang ada di perusahaan.Hasil penelitian menunjukkan bahwa kompensasi langsung berpengaruh positif dan signifikan terhadap kinerja karyawan bagian staff operasional PT Pranata Jaya Abadi sebesar .

Hasil penelitian menunjukkan bahwa kompensasi tidak langsung berpengaruh positif dan signifikan terhadap kinerja karyawan bagian staff operasional PT Pranata Jaya Abadi sebesar .

Hasil penelitian menunjukkan bahwa kompensasi langsung dan kompensasi tidak langsung berpengaruh positif dan signifikan terhadap kinerja karyawan bagian staff operasional PT Pranata Jaya Abadi sebesar.

Dalam pemberian kompensasi langsung di PT Pranata Jaya Abadi dirasa masih kurang. Karyawan masih banyak yang mengeluh dan merasa belum puas atas gaji/upah yang diberikan. Pemberian kompensasi hendaklah berasakan pada keadilan, transparan, taat aturan dan sesuai atas jabatan para 
karyawan. Jabatan yang tinggi tentunya mempunyai tanggung jawab yang tunggi pula, hendaklah perusahaan mengadakan sistem pemberian premi jabatan yang akan membuat karyawan merasa dihargai. Dengan pemberian kompensasi langsung yang baik diharapakan dapat memberikan kesejahteraan kepada karyawan, dan membuat para karyawan meningktakan kinerja mereka sehingga target perusahaan tercapai.

Kompensasi tidak langsung yang diberikan dapat lebih divariasikan. Dibandingkan dengan darmawisata yang tidak efektif. Lebih baik sebelum melakukan darmawisata dilakukan survey terlebih dahulu. Agar lebih efektif dirasakan manfaatnya , jika darmawisata yang dilakukan sesuai dengan tujuan perusahaan dan harapan dari karyawan akan lebih efesien dan efektif. Mayoritas para karyawan lebih mengingikan family trip, dibandingkan dengan team building, usia yang sudah tidak muda membuat para karyawan menjadi kelelahan dan merasa bahwa perusahaan telah membuang uang dengan Cuma-cuma. . Program Kompensasi tidak langsung sangatlah variatif, bisa dengan mengadakan program cicilan perumahan sangatlah lebih efektif dan tentunya bisa memicu para karyawan agar berkinerja lebih baik. Namun semua bergantung terhadap stabilitas keuangan perusahaan.

\section{DAFTAR PUSTAKA}

Arikunto, S. (20 13). Prosedur Penelitian

Suatu Pendekatan Praktek. Jakarta: Rineka Cipta.

Ghozali, Imam (2011). Aplikasi Analisis Multivariate Dengan Program SPSS . Semarang : BP Universitas Diponegoro.

Handoko, T. (2011). Manajemen. Yogyakarta: BPFE.

Hasibuan, M. S. (2013). Manajemen Sumber Daya Manusia. Edisi Revisi, cetakan kesepuluh. Jakarta: PT BUmi Aksara.

Mangkunegara, A. P. (2013). Manajemen Sumber Daya Manusia. Cetakan kesepuluh. Bandung: PT Remaja Rosdakarya Offset.

Manullang M, M. (2012). Manajemen Sumber Daya Manusia, (Edisi-10). Yogyakarta: BPFE.

Mathis, Robert L dan H Jackson. (2012). Manajemen Sumber Daya Manusia, Edisi Kesepuluh. Jakarta: Salemba Empat.

Nawawi, H. (2013). Kepemimpinan Yang Efektif. Yogyakarta: UGM Press.

Robbins, d. (2013). Perilaku Organisasi , Buku 1 dan 2 . Jakarta: Salemba Empat.

Simamora, H. (2012). Manajemen Sumber Daya Manusia. Edisi Kesebelas. Yogyakarta: STIE YKPN. 
Sugiyono. (2013). Metode Penelitian

Kuantitatif, Kualitatif dan $R \& D$.

Bandung: CV Alfabeta.

Umar, H. (2009). Metode Riset Perilaku

Organisasi. Jakarta: Gramedia.

JURNAL :

Fauzi, Usman. 2014. Pengaruh kompensasi terhadap kinerja karyawan pada PT Trakindo Utama Samarinda.

Dito, Anoki Herdian. 2010. Pengaruh kompensasi langsung dan kompensasi tidak langsung terhadap kinerja karyawan PT Slamet Langgeng Purbalingga

PENELITIAN TERDAHULU :

Laura, Hana. 2010. Pengaruh kompensasi langsung dan kompensasi tidak langsung terhadap kinerja karyawan (Studi Kasus di Ruang Perawatan VIP Anggrek dan Ruang Perawatan K, RS PGI Cikini Jakarta)

Saifuddin, Ahmad Rohim. 2015. Pengaruh kompensasi langsung dan kompensasi tidak langsung terhadap kinerja karyawan KJKS BMT AMANAH UMMAH. 